\title{
Self-Regulated Learning Strategies And Pre-University Math Performance Of International Students In Malaysia
}

Tang Eng Loong, Sunway College, Malaysia

\begin{abstract}
This study is an attempt to compare the use of self-regulated learning strategies and their math performance between home and international students in the Monash University Foundation Year (MUFY) and determine the self-regulated learning strategies that are significantly associated with their math performance. The participants of the study were 80 home students and 76 international students, where majority of the participants were in their first semester. The Learning and Study Strategies Inventory (LASSI) was used to measure students' self-regulated learning strategies, while the math performance was measured by the final score of Fundamental Mathematics A taken in the pre-university program. The results of statistical analysis revealed that the pass rate of home students was significantly better than international students, and international students scored significantly higher than home students in Anxiety, Self-Testing and Time Management subscales of the LASSI. The results also revealed that Attitude and Self-Testing subscales were significant predictors of home students' math performance, while Attitude and Test Strategies subscales were significant predictors of international students' math performance. The results have significant implications for academic advising and counseling of newly arrived students, both home and international students, in the pre-university program.
\end{abstract}

Keywords: Self Regulated Learning Strategies; Math Performance; Malaysian students; International Students

\section{INTRODUCTION}

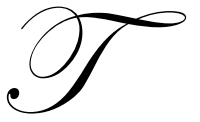

he number of international students in Malaysian private higher education institutions had increased by $15 \%$ between 2008 and 2009, bringing the number from 50,679 to 58,294. In 2010, the number of international students in Malaysian private higher education institutions was 62,705, where 65\% were Asian and 27\% were African (Ministry of Higher Education, 2008, 2009, 2010). The flow of international students into Malaysian private higher education institutions was due to various higher education reforms introduced by the government.

Many studies on international students in Malaysian higher education institutions have investigated the factors that determine international students' choice in choosing Malaysia as their destination of higher education (British Council, 2008; Morshidi Sirat, 2008; National Higher Education Research Institute, 2009; Rohana Jani et al., 2010; Rohaizat Baharun et al., 2011). The determinants of the inflow of international students are important, but their academic performance should not be neglected. In Western countries, studies have been conducted to examine the academic performance of international students as compared to home students. Home students did well than international students at the UK polytechnic sector (Makepeace \& Baxter, 1990). International students dominated the group that obtained third class and unclassified degrees in the School of Surveying at Kingston University (Smith \& Eccles, 1993). International students in a first-year business studies program obtained lower marks in some forms of assessment than home students at a UK university (De Vita, 2002). Among engineering students at a Dutch university, international students obtained the same pass rate as home students, but took longer time to pass their examinations (Jochems et al., 1996). Morrison et al. (2005) analyzed data collected by the Higher Education Statistics Agency (HESA) and found that, overall UK undergraduate students did significantly better than overseas 
counterparts. On the other hand, several studies suggested that international students did better than home students. Overseas-fee-paying students outperformed the general student body at Curtin University of Technology, Australia (Pauley, 1988). Another Australian study at Murdoch University found that overseas students performed as well as, or better than home students (Williams, 1989). Dobson et al. (1998) analyzed data collected by the Student Progress Units in Australia found that, on average, overseas undergraduate outperformed non-overseas counterparts. In Malaysia, such published research on international students is very rare for both private and public institutions of higher education.

In recent years, many international students have chosen MUFY as their preferred pre-university program to Monash University. As recorded in student database in September 2011, there were 729 students in the preuniversity program at Sunway College in Bandar Sunway, of that $25 \%$ were international students who mainly came from Asian and African countries (Maheshchandar B., personal communication, September 19, 2011). The substantial number of international students suggests that students in classrooms are so diversified in various aspects. One of the aspects is the use of self-regulated learning strategies, which is described as the process by which learners personally activate and sustain cognitions, affects, and behaviors that are systematically oriented towards achieving learning goals (Schunk \& Zimmerman, 2008), whereas, Purdie, Hattie and Douglas (1996) describes selfregulated learners as self-initiators who exercise choice of control over the methods needed to obtain the learning goals they set for themselves.

Numerous empirical studies have examined the relationship between the use of self-regulated learning strategies and academic performance. Nist et al. (1990) reported that motivation, anxiety, and self-testing were correlated moderately with postsecondary students' semester performance. Hulick and Higginson (1989) reported that college freshmen who possessed higher level in attitude, motivation, anxiety, concentration, information processing and test strategies achieved higher grade point average (GPA) at the completion of their first year. Yip and Chung (2005) documented the differences on the use of learning strategies between matriculation and university students. They found that selecting main idea, attitude, study aids, motivation, time management, self-testing, and test strategies were the significant indicators for their mean GPA of matriculation students, and for university students, concentration and motivation were the significant indicators of their mean GPA. Reaser et al. (2007) reported that motivation was the significant and positive predictor of GPA for undergraduate students in each of attention-deficit/hyperactivity disorder and non-disability groups, and anxiety was the significant and positive predictor of GPA of students with learning disabilities. Kamariah Abu Bakar et al. (2010) found that achievement motivation was significantly and negatively correlated with their cumulative GPA and attitude toward studying was significantly and positively correlated with their cumulative GPA of undergraduates at a Malaysian public university. However, the overall academic performance in these studies may not truly reflect math performance of students, and also the use of self-regulated learning strategies in different subjects may be varied. In addition, past literature offered little understanding on the relationship between the use of self-regulated learning strategies and math performance at pre-university level. Belcheir (2002) reported that motivation was a significant and negative predictor of undergraduates' performance in immediate algebra. MacNamara and Penner (2005) reported that time management, motivation, concentration and study aids were significantly and positively correlated with their final math results, while anxiety was significantly and negatively correlated with their math results of the first year college students major in mathematics. Wadsworth et al. (2007) found that motivation, concentration and information processing were significant and positive in predicting the final grade of the online math course of college students, but self-testing was a negative and significant predictor of the online math course grade.

Previous cross-cultural studies have used different inventories to measure and compare the use of selfregulated learning strategies between students in two different countries (Purdie, Hattie \& Douglas, 1996; Alexander et al., 1998; Olaussen \& Braten, 1999; Turingam \& Yang, 2009; Pillay, Purdie \& Boulton-Lewis, 2000). For example, Alexander et al. (1998) compared self-regulated learning strategies of $9^{\text {th }}$ grade female students in Singapore with average or above average academic ability with $9^{\text {th }}$ grade American students of average and gifted academic ability, and they found that, on average, Singaporean students were less motivated, more anxious and better at using study aids than their American counterparts. Olaussen and Braten (1999) investigated the differences on the use of self-regulated learning strategies between American and Norwegian students at the post-secondary level, and they found that American students were more motivated and possessed less positive attitude toward learning than Norwegian students. These studies have contributed significantly to our understanding of the use of 
self-regulated learning strategies between students in different cultures. However, the level of cultural differences in these studies was much narrow as compared to international students. Furthermore, there is very limited literature on the use of self-regulated learning strategies among international students and its effect on academic performance. Stoynoff (1996) documented that high- and low-achieving international students used many of the same selfregulated learning strategies. Stoynoff (1997) found that motivation, self-testing and test strategies were significantly and positively correlated with their GPA among freshman international students.

The present study examines how self-regulated learning strategies affect math performance for both home and international students. It provides an insight into which self-regulated learning strategies influence significantly on their math performance, so that the Pre-University Studies division at the college can provide assistance to students especially international students who are new to the learning environment to achieve optimal performance in math. The present study evaluates the following research questions:

1. Is there any difference on math performance between home and international students?

2. Are there any differences on the LASSI subscales between home and international students?

3. Which LASSI subscales are the significant predictors of the performance of home students in math?

4. Which LASSI subscales are the significant predictors of the performance of international students in math?

\section{Monash University Foundation Year}

MUFY is a two-semester (about 10 months) program, which provides a successful pathway from secondary schools to Monash University. Students have the option of completing the program in more than two semesters. The program offers various subjects and each subject is divided into two units: part A and part B. Three of the subjects offered are mathematical subjects, namely Fundamental Mathematics, Mathematics and Advanced Mathematics. Fundamental Mathematics is the most manageable mathematical subject, which is equivalent to Year 11 Mathematics. Students must pass Fundamental Mathematics A before they are allowed to do Fundamental Mathematics B. The selection of mathematical subjects at MUFY determines the degree programs students will be taking at Monash University. For example, students who plan to take business degree programs at that university are required to do Fundamental Mathematics, while students who plan to do engineering degree programs are required to take Mathematics.

\section{METHODOLOGY}

\section{Participants}

156 students (79 males, 77 females) who registered for Fundamental Mathematics A in July 2010 (51 students), August 2010 (14 students), July 2011 (63 students) and August 2011 (28 students) semesters participated in the research study at Sunway College in Bandar Sunway. All students in July and August 2010 semesters were taught by the same instructor, whereas students in each of July and August 2011 semesters were taught by two different instructors.

There were 80 home students (40 males, 40 females) and 76 international students ( 39 males, 37 females). Both home and international students ranged in age from 16 to 24 years $(M=18.16, S D=.91$ for home students, and $\mathrm{M}=18.39, \mathrm{SD}=1.51$ for international students). International students came from 26 countries and their numbers are as shown below: Indonesia (10), Sri Lanka (8), Bangladesh (7), Pakistan (5), China (4), Saudi Arabia (4), Uganda (4), Bahrain (3), Kazakhstan (3), Kenya (3), Maldives (3), South Korea (3), Vietnam (3), Iran (2), Nigeria (2), Sudan (2), Bosnia (1), Guinea (1), India (1), Jordan (1), Mauritius (1), Singapore (1), Taiwan (1), Tajikistan (1), Thailand (1) and Zimbabwe (1). International students were summarized according to geographical regions which can be seen in Table 1.

91.2\% of home students completed Sijil Pelajaran Malaysia (SPM) or Malaysian Certificate of Education, and the rest completed General Certificate of Education (GCE) O-Level, General Certificate of Secondary Education (GCSE) O-Level and International General Certificate of Secondary Education (IGCSE) O-Level. International students' educational background: GCE O-Level (26.3\%), IGCSE O-Level (11.8\%), Ujian Akhir Nasional (UAN) or 
National Final Exam (9.2\%), Secondary School Certificate (SSC) (3.9\%), Uganda Advanced Certificate of Education Exam (UACE) (3.9\%), GCSE O-Level (2.6\%), Hui Kao or National Senior High School Graduation Examination (2.6\%), others (30.5\%) and no response (9.2\%). 124 students (53.2\% home, $46.8 \%$ international) were in their first semester, 22 students were in their second semester (40.9\% home, 59.1\% international) and 10 students were in their third semester (50\% home, 50\% international). Among the total 156 students, 4 international students did not have the final score due to the students not sitting for their final exam.

Table 1: Composite Of International Students According To Geographical Regions

\begin{tabular}{|c|c|c|}
\hline Region & $\mathbf{N}$ & $\%$ \\
\hline South Asia & 24 & 31.6 \\
\hline Asia Pacific & 23 & 30.3 \\
\hline Africa & 14 & 18.4 \\
\hline Middle East & 10 & 13.2 \\
\hline Central Asia & 4 & 5.3 \\
\hline Other & 1 & 1.2 \\
\hline Total & 76 & 100.0 \\
\hline
\end{tabular}

\section{Instruments}

Questionnaire consists of demographic questions and educational information: gender, age, nationality, secondary school examination, and number of semesters in the pre-university program.

The $2^{\text {nd }}$ Edition of the LASSI (Weinstein, Palmer \& Shulte, 2002) consists of 80 items in which students respond to questions using 5-point ratings that range from not at all typical of me to very much typical of me. The inventory is both diagnostic and prescriptive, measuring students' use of learning and study strategies in the areas of skill, will, and self-regulation. Specifically, the inventory contains 10 subscales:

1. Anxiety - feelings of worry towards school and tests despite being well prepared.

2. Attitude - interest in and attitude towards school; desire to work on academic tasks.

3. Concentration - ability to pay attention to, concentrate on, and think about the learning materials; will not be easily distracted.

4. Information Processing - the use of verbal and imaginational elaboration; strategies of organizing and interrelating information; skills of comprehending, reasoning, and use of logic.

5. Motivation - desire and willingness to work hard; level of motivation and incentive for school; selfdiscipline.

6. Self-Testing - regular review of course materials; checks of the comprehension level attained; preparation for the lesson.

7. Selecting Main Ideas - ability to figure out the critical points and key ideas in the course materials and focus on these during studying.

8. Study Aids - good use of various aids and techniques to support learning; use of key words, examples, headings, and diagrams to help learning.

9. Time Management - create and use schedules to manage their responsibilities effectively.

10. Test Strategies - knowledge of different types of tests and the necessary preparation for them.

The internal consistency reliability coefficients (Cronbach's alpha) for subscales as reported in the manual of the LASSI are: Anxiety $(\alpha=.87)$, Attitude $(\alpha=.77)$, Concentration $(\alpha=.86)$, Information Processing $(\alpha=.84)$, Motivation $(\alpha=.84)$, Self-Testing $(\alpha=.84)$, Selecting Main Ideas $(\alpha=.89)$, Study Aids $(\alpha=.73)$, Time Management $(\alpha=.85)$, and Test Strategies $(\alpha=.80)$.

\section{Math Assessment}

The syllabus of Fundamental Mathematics A consists of six topics: Number Systems, Fractions, Decimals and Percentage, Algebra, Ratio and Proportion, Sequence and Series, and Business Mathematics. The final score of the subject is calculated based on two components: coursework mark (40\%), which is based on five topic tests and 
all have the same weight, and final exam (60\%), which covers all the topics. The final score of the subject is used to assess students' math performance. The grade distribution is as follows: High Distinction (80\% or above), Distinction ( $70 \%$ to $79 \%$ ), Credit (60\% to $69 \%)$, Pass $(50 \%$ to $59 \%$ ) and Fail (49\% or below). The pass rate is defined as the percentage of students achieved 'Pass' or better grades.

\section{Data Collection Procedure And Data Analysis}

The survey was conducted during math classes two weeks before their semesters end. Students were briefed on the purpose of the survey and then were given an informed consent form, the questionnaire and the $2^{\text {nd }}$ Edition of the LASSI (Weinstein, Palmer \& Shulte, 2002). All students completed the consent form, the questionnaire and the LASSI in classrooms. The final score of the subject was then obtained from student data record at the end of each semester. The collected data were entered into the SPSS version 19. Subsequently, the data were used to assess the objectives of the study.

\section{RESULTS}

\section{Math Performance Between Home and International Students}

The grade distribution for home and international students can be seen in Table 2. The means and standard deviations of the final score and pass rate for the two groups and the results of the Independent Samples t-test are displayed in Table 3. The results of the Independent Samples t-test showed that home students performed significantly better than international students in terms of the pass rate $(\mathrm{t}(130.911)=2.164$, $\mathrm{p}<.05)$, but no significant difference based on the mean final score $(\mathrm{t}(129.943)=1.385, \mathrm{p}=.169)$.

Table 2: Math Grades Between Home And International Students

\begin{tabular}{lccc}
\hline \multirow{2}{*}{ Grade } & & $\mathbf{N}$ & \multirow{2}{*}{ Total } \\
\cline { 2 - 3 } & Home & International & 45 \\
High Distinction & 22 & 23 & 33 \\
Distinction & 20 & 13 & 22 \\
Credit & 14 & 8 & 23 \\
Pass & 14 & 9 & 29 \\
Fail & 10 & 19 & 152 \\
\hline Total & 80 & 72 & \\
\hline
\end{tabular}

Table 3: Descriptive Statistics And Independent Samples t-test On Final Math Score And Pass Rate Between Home And International Students

\begin{tabular}{|c|c|c|c|c|c|c|c|c|c|}
\hline \multirow[t]{2}{*}{ Variable } & \multicolumn{2}{|c|}{$\begin{array}{c}\text { All } \\
(N=152)\end{array}$} & \multicolumn{2}{|c|}{$\begin{array}{c}\text { Home } \\
(\mathbf{N}=\mathbf{8 0})\end{array}$} & \multicolumn{2}{|c|}{$\begin{array}{c}\text { International } \\
(\mathbf{N}=72)\end{array}$} & \multirow[t]{2}{*}{ MD } & \multirow[t]{2}{*}{ SE } & \multirow[t]{2}{*}{ CI } \\
\hline & $\mathrm{M}$ & SD & $\mathrm{M}$ & SD & M & SD & & & \\
\hline Final Math Score & 65.26 & 20.97 & 67.52 & 17.73 & 62.75 & 23.94 & 4.78 & 3.45 & $(-2.05,11.60)$ \\
\hline Pass Rate & .81 & .39 & .88 & .33 & .74 & .44 & .14 & .06 & $(.01, .27)$ \\
\hline
\end{tabular}

Note: $\mathrm{MD}=$ Mean difference

\section{LASSI Subscales Between Home and International Students}

For the present study, the following reliability coefficients (Cronbach's Alpha) were obtained: Anxiety ( $\alpha=$ $.82)$, Attitude $(\alpha=.79)$, Concentration $(\alpha=.76)$, Information Processing $(\alpha=.70)$, Motivation $(\alpha=.74)$, Self-Testing $(\alpha=.74)$, Selecting Main Ideas $(\alpha=.82)$, Study Aids $(\alpha=.60)$, Time Management $(\alpha=.69)$, and Test Strategies $(\alpha=$ .77). All the subscales showed acceptable levels of reliability, apart from Study Aids and Time Management subscales.

The bivariate correlation between two subscales of the LASSI for all students, home and international students can be seen in Table 4. For all students, 32 were significantly and positively correlated among 45 bivariate 
correlations, and only one pair was significantly and negatively correlated, which is between Study Aids and Anxiety subscales. The strongest positive correlation was between Test Strategies and Selecting Main Ideas subscales.

A MANOVA was conducted to test the hypothesis of differences between home and international students on the 10 LASSI subscales. Wilks' Lambda of .882 and $\mathrm{F}(10,145)=1.932, \mathrm{p}<.05$, revealed significant differences between the two groups on the subscales. Subsequently, a series of Independent Samples t-test was conducted on individual subscales and the test statistics for the LASSI subscales were: Anxiety $(\mathrm{t}(154)=-2.115, \mathrm{p}<.05)$, Attitude $(\mathrm{t}(154)=.478, \mathrm{p}=.633)$, Concentration $(\mathrm{t}(154)=-1.463, \mathrm{p}=.146)$, Information Processing $(\mathrm{t}(154)=.137, \mathrm{p}=$ $.891)$, Motivation $(\mathrm{t}(154)=-.058, \mathrm{p}=.954)$, Self-Testing $(\mathrm{t}(154)=-2.131, \mathrm{p}<.05)$, Selecting Main Ideas $(\mathrm{t}(154)=-$ $.465, \mathrm{p}=.643)$, Study Aids $(\mathrm{t}(142.420)=-.885, \mathrm{p}=.378)$, Time Management $(\mathrm{t}(144.303)=-2.271, \mathrm{p}<.05)$ and Test Strategies $(\mathrm{t}(154)=.503, \mathrm{p}=.615)$. The mean and standard deviation for each LASSI subscale and the results of the Independent Sample t-test can be seen in Table 5. The test revealed that international students were significantly higher than home students in the following three subscales: Anxiety, Self-Testing and Time Management.

Table 4: Bivariate Correlations Between LASSI Subscales For All Students, Home And International Students

\begin{tabular}{|c|c|c|c|c|c|c|c|c|c|c|c|}
\hline & & ANX & ATT & CON & INP & MOT & SFT & SMI & STA & TMT & TST \\
\hline ANX & & 1 & & & & & & & & & \\
\hline \multirow[t]{3}{*}{ ATT } & $\mathrm{a}$ & $.224 * *$ & 1 & & & & & & & & \\
\hline & b & .187 & & & & & & & & & \\
\hline & $\mathrm{c}$ & $.293 *$ & & & & & & & & & \\
\hline \multirow[t]{3}{*}{$\mathrm{CON}$} & $\mathrm{a}$ & $.448 * *$ & $.398 * *$ & 1 & & & & & & & \\
\hline & $\mathrm{b}$ & $.424 * *$ & $.471^{* *}$ & & & & & & & & \\
\hline & $\mathrm{c}$ & $.456^{* * *}$ & $.331 * *$ & & & & & & & & \\
\hline \multirow{3}{*}{ INP } & $\mathrm{a}$ & .016 & .148 & $.269 * *$ & 1 & & & & & & \\
\hline & $\mathrm{b}$ & .088 & $.321 * *$ & $.260 *$ & & & & & & & \\
\hline & $\mathrm{c}$ & -.059 & .020 & $.286^{*}$ & & & & & & & \\
\hline \multirow[t]{3}{*}{ MOT } & $\mathrm{a}$ & .089 & $.358 * *$ & $.474 * *$ & $.529 * *$ & 1 & & & & & \\
\hline & $\mathrm{b}$ & -.043 & $.365^{* *}$ & $.467 * *$ & $.581 * *$ & & & & & & \\
\hline & $\mathrm{c}$ & $.250 *$ & $.352 * *$ & $.489 * *$ & $.481 * *$ & & & & & & \\
\hline \multirow[t]{3}{*}{ SFT } & $\mathrm{a}$ & -.123 & .095 & $.362 * *$ & $.446^{* *}$ & $.471 * *$ & 1 & & & & \\
\hline & $\mathrm{b}$ & -.125 & .200 & $.369 * *$ & $.430 * *$ & $.557 * *$ & & & & & \\
\hline & $\mathrm{c}$ & -.193 & .003 & $.329 * *$ & $.477 * *$ & $.397 * *$ & & & & & \\
\hline \multirow[t]{3}{*}{ SMI } & $\mathrm{a}$ & $.422 * *$ & $.401 * *$ & $.564 * *$ & $.311^{* *}$ & $.459 * *$ & .076 & 1 & & & \\
\hline & $\mathrm{b}$ & $.378^{* *}$ & $.448 * *$ & $.585^{* *}$ & $.361 * *$ & $.377 * *$ & .193 & & & & \\
\hline & $\mathrm{c}$ & $.478 * *$ & $.356^{* *}$ & $.514 * *$ & $.266^{*}$ & $.543 * *$ & -.052 & & & & \\
\hline \multirow[t]{3}{*}{ STA } & $\mathrm{a}$ & $-.163^{*}$ & -.050 & .154 & $.315^{* *}$ & $.388 * *$ & $.511 * *$ & -.045 & 1 & & \\
\hline & $\mathrm{b}$ & -.209 & .044 & .101 & .134 & $.383 * *$ & $.478 * *$ & -.060 & & & \\
\hline & $\mathrm{c}$ & -.156 & -.125 & .192 & $.455^{* *}$ & $.398 * *$ & $.536^{* *}$ & -.039 & & & \\
\hline \multirow[t]{3}{*}{ TMT } & $\mathrm{a}$ & .123 & $.276^{* * *}$ & $.643 * *$ & $.266^{* * *}$ & $.464 * *$ & $.505^{* *}$ & $.312 * *$ & $.346^{* *}$ & 1 & \\
\hline & $\mathrm{b}$ & .081 & $.385^{* *}$ & $.700 * *$ & .159 & $.390 * *$ & $.507 * *$ & $.225^{*}$ & $.317 * *$ & & \\
\hline & $\mathrm{c}$ & .122 & .155 & $.549 * *$ & $.435^{* *}$ & $.601 * *$ & $.483 * *$ & $.441^{* *}$ & $.394 * *$ & & \\
\hline \multirow[t]{3}{*}{ TST } & $\mathrm{a}$ & $.500 * *$ & $.407 * *$ & $.570 * *$ & $.246^{* *}$ & $.474 * *$ & -.015 & $.729 * *$ & -.070 & $.288 * *$ & 1 \\
\hline & $\mathrm{b}$ & $.471 * *$ & $.415^{* *}$ & $.634 * *$ & $.408 * *$ & $.416 * *$ & .083 & $.777 * *$ & -.171 & $.266^{*}$ & \\
\hline & $\mathrm{c}$ & $.571^{* *}$ & $.398^{* *}$ & $.524 * *$ & .100 & $.531 * *$ & -.096 & $.689^{* *}$ & .013 & $.359 * *$ & \\
\hline
\end{tabular}

Note: Row a for all students, row b for home students, row c for international students. ANX = Anxiety; ATT = Attitude; CON = Concentration; INP = Information Processing; MOT = Motivation; SFT = Self-Testing; SMI = Selecting Main Ideas; STA = Study Aids; TMT $=$ Time Management; TST $=$ Test Strategies. $*$ Correlation is significant at the 0.05 level; ** Correlation is significant at the 0.01 level 
Table 5: Descriptive Statistics Of LASSI Subscales

And Independent Samples t-test On LASSI Subscales Between Home And International Students

\begin{tabular}{|c|c|c|c|c|c|c|c|c|c|}
\hline \multirow[t]{2}{*}{$\begin{array}{l}\text { LASSI } \\
\text { Subscale }\end{array}$} & \multicolumn{2}{|c|}{$\begin{array}{c}\text { All } \\
(\mathrm{N}=156) \\
\end{array}$} & \multicolumn{2}{|c|}{$\begin{array}{c}\text { Home } \\
(\mathbf{N}=\mathbf{8 0})\end{array}$} & \multicolumn{2}{|c|}{$\begin{array}{c}\text { International } \\
(\mathrm{N}=76)\end{array}$} & \multirow[t]{2}{*}{ MD } & \multirow[t]{2}{*}{ SE } & \multirow[t]{2}{*}{ CI } \\
\hline & $\mathbf{M}$ & SD & $\mathbf{M}$ & SD & $\mathbf{M}$ & SD & & & \\
\hline ANX & 21.98 & 6.47 & 20.92 & 6.83 & 23.09 & 5.90 & -2.17 & 1.02 & $(-4.19,-.14)$ \\
\hline ATT & 28.53 & 6.16 & 28.76 & 6.21 & 28.29 & 6.14 & .47 & .99 & $(-1.48,2.43)$ \\
\hline $\mathrm{CON}$ & 24.83 & 5.29 & 24.22 & 5.47 & 25.46 & 5.06 & -1.24 & .84 & $(-2.90, .43)$ \\
\hline INP & 28.03 & 4.60 & 28.08 & 4.41 & 27.97 & 4.82 & .10 & .74 & $(-1.36,1.56)$ \\
\hline MOT & 28.66 & 4.98 & 28.64 & 4.96 & 28.68 & 5.04 & -.05 & .80 & $(-1.63,1.54)$ \\
\hline SFT & 23.42 & 5.19 & 22.56 & 5.05 & 24.32 & 5.22 & -1.75 & .82 & $(-3.38,-.13)$ \\
\hline SMI & 27.53 & 5.35 & 27.34 & 5.31 & 27.74 & 5.42 & -.40 & .86 & $(-2.10,1.30)$ \\
\hline STA & 24.93 & 4.56 & 24.61 & 4.00 & 25.26 & 5.08 & -.65 & .74 & $(-2.10, .80)$ \\
\hline TMT & 24.08 & 5.02 & 23.21 & 5.64 & 25.00 & 4.10 & -1.79 & .79 & $(-3.34,-.23)$ \\
\hline TST & 26.68 & 5.28 & 26.89 & 5.11 & 26.46 & 5.48 & .43 & .85 & $(-1.25,2.10)$ \\
\hline
\end{tabular}

Note: $\mathrm{MD}=$ Mean difference

\section{LASSI Subscales Predicting Final Math Score For Home And International Students}

A multiple linear regression model was used to fit into the collected data with the final math score as the dependent variable and the 10 LASSI subscales as the independent variables. The coefficients of the regression models can be seen in Table 6. The analysis revealed that Attitude and Test Strategies were significant and positive predictors of the final math score for all the students $\left(\mathrm{R}^{2}=.375\right.$, adjusted $\left.\mathrm{R}^{2}=.331, \mathrm{~F}(10,141)=8.475, \mathrm{p}<.001\right)$. For home students, Attitude and Self-Testing were significant and positive predictors of the final score $\left(\mathrm{R}^{2}=.359\right.$, adjusted $\left.\mathrm{R}^{2}=.266, \mathrm{~F}(10,69)=3.863, \mathrm{p}<.001\right)$, whereas, for international students, Attitude and Test Strategies were the significant and positive predictors of the final score $\left(\mathrm{R}^{2}=.457\right.$, adjusted $\mathrm{R}^{2}=.368, \mathrm{~F}(10,61)=5.142, \mathrm{p}<$ $.001)$.

Table 6: Unstandardized And Standardized Coefficients For Regression Model Predicting Final Math Score of Home And International Students

\begin{tabular}{|c|c|c|c|c|c|c|c|c|c|c|c|c|}
\hline \multirow[t]{2}{*}{$\begin{array}{c}\text { LASSI } \\
\text { Subscale }\end{array}$} & \multicolumn{4}{|c|}{$\begin{array}{c}\text { All } \\
(\mathrm{N}=152)\end{array}$} & \multicolumn{4}{|c|}{$\begin{array}{c}\text { Home } \\
(\mathbf{N}=\mathbf{8 0})\end{array}$} & \multicolumn{4}{|c|}{$\begin{array}{c}\text { International } \\
(\mathbf{N}=72)\end{array}$} \\
\hline & B & SE & Beta & p & B & SE & Beta & p & B & SE & Beta & $\mathbf{p}$ \\
\hline ANX & .30 & .27 & .09 & .277 & .56 & .32 & .22 & .084 & -.20 & .53 & -.05 & .705 \\
\hline ATT & 1.74 & .26 & .51 & $.000 * *$ & 1.38 & .34 & .48 & $.000 * *$ & 2.04 & .42 & .53 & $.000^{* *}$ \\
\hline $\mathrm{CON}$ & -.72 & .45 & -.18 & .117 & -.43 & .65 & -.13 & .507 & -.61 & .69 & -.13 & .382 \\
\hline INP & -.21 & .38 & -.05 & .579 & -.36 & .53 & -.09 & .495 & .18 & .61 & .04 & .768 \\
\hline MOT & .13 & .43 & .03 & .753 & -.27 & .55 & -.08 & .623 & .78 & .74 & .17 & .295 \\
\hline SFT & .32 & .39 & .08 & .414 & 1.09 & .50 & .31 & $.034 *$ & -.58 & .66 & -.13 & .384 \\
\hline SMI & -.62 & .41 & -.16 & .128 & -.22 & .55 & -.07 & .686 & -1.13 & .68 & -.26 & .102 \\
\hline STA & .08 & .38 & .02 & .834 & -.16 & .54 & -.04 & .764 & .17 & .58 & .04 & .775 \\
\hline TMT & -.54 & .40 & -.13 & .178 & -.55 & .52 & -.17 & .291 & -.75 & .80 & -.13 & .355 \\
\hline TST & 1.49 & .45 & .38 & $.001 * *$ & 1.02 & .66 & .29 & .130 & 1.67 & .67 & .39 & $.015^{*}$ \\
\hline
\end{tabular}

Note: $\mathrm{B}=$ Unstandardized coefficient, Beta $=$ Standardized coefficient; $*$ Significant at the 0.05 level; $* *$ Significant at the 0.01 level

\section{DISCUSSION}

The current study provides important information concerning international students' math performance as compared to home students in the pre-university program and their differences in the self-regulated learning strategies as well as the effects of the learning strategies on math performance. There was no significant difference between home and international students based on the mean score of the mathematical subject, but the pass rate of home students was significantly higher than international students. The finding on the pass rate was consistent with De Vita's finding (2002) even though both studies were conducted on students at two different educational levels. This suggests that international students with weak math skills should be identified at the beginning of semester. 
This is very important as more and more international students choose the pre-university program as their pathway to Monash University. Perhaps a remedial class should be provided to those who are weak in math for both home and international students in the pre-university program.

The cultural and educational backgrounds of international students were so much different as compared to home students. However, only three of the LASSI subscales of international students were significantly higher than home students, namely Anxiety, Self-Testing and Time Management. The result demonstrated that international students possessed good techniques in self-testing and time management than home students. However, international students possessed a higher anxiety level than Malaysian counterparts. This was anticipated as majority of international students participated in the survey were in their first semester in the program in which the learning environment was new to them. And also for some international students, this was the first time they sit for math tests written in English. This implies that the instructors of the mathematical subject should be sensitive to this behavior and try to understand their challenges to adapt to new learning environment. Perhaps a supportive program should be held to help international students to reduce their anxiety and make them comfortable to the new learning environment of the program.

The correlation analysis showed no significant correlation between Anxiety subscale and each of SelfTesting and Time Management subscales among international students, but there was a moderate correlation between Self-Testing and Time Management subscales. The result demonstrated that anxiety did not cause international students to be focused more on self-testing and time management techniques while learning math.

For home students, Attitude and Self-Testing subscales were significant and positive predictors of the preuniversity math performance. The two subscales were also reported to be significantly correlated with students' overall academic performance measured by semester performance (Nist et al., 1990), GPA (Hulick \& Higginson, 1989), mean GPA (Yip \& Chung, 2005) and cumulative GPA (Kamariah Abu Bakar et al., 2010). However, Attitude subscale did not appear to be significantly correlated with the math performance as reported by Belcheir (2002), MacNamara and Penner (2005) and Wadsworth et al. (2007). One possible explanation for Attitude subscale to be a significant predictor of math performance is that Fundamental Mathematics A is an exam-orientated subject, where the assessment format involves topic tests and final exam. Therefore, students have to have positive attitude while learning the subject in the traditional learning environment. The positive correlation between Self-Testing subscale and the math performance in this study contrasted with the finding by Wadsworth et al. (2007), which reported a negative correlation. One possible explanation for the inconsistency is students in Wadsworth et al.'s study learn math in the online learning environment.

For international students in the pre-university program, Attitude and Test Strategies subscales were significant and positive predictors of the math performance. Test Strategies subscale also appeared to be significantly and positively correlated with GPA among freshman international students in Stoynoff's study (1997). Certainly, international students have to have good test strategies in math as the mathematical subject is examorientated.

The determinants of international students' math performance are complex and not fully understood. The present study only explores the use of self-regulated learning strategies, but this is not the only factor that influences their math performance. Researchers should continue exploring factors that are not measured by self-regulated learning strategies. English proficiency, math placement and educational background are among the interesting factors worth to be explored in the future research.

\section{AUTHOR INFORMATION}

Tang Eng Loong is a lecturer in the Monash University Foundation Year at Sunway College in Malaysia. His research interest is to determine factors that are associated with students' math performance in the pre-university program. E-mail: lawrencet@sunway.edu.my 


\section{REFERENCES}

1. Alexander, P.A., Murphy, P.K., \& Guan, J. (1998). The learning and study strategies of highly able female students in Singapore. Educational Psychology, 18(4), 391-407.

2. Belcheir, M.J. (2002). What predicts success in intermediate algebra? Research report 2002-2006 (Boise State University). Retrieved 8 November, 2010 from http://www.boisestate.edu/iassess/reports/2002/RR2002-06.pdf

3. British Council (2008). International student mobility in East Asia: Executive summary. Retrieved 12 October, 2011 from http://www.eahep.org/web/images/Malaysia/bc\%20\%20asia\%20student\%20mobility\%20-\%20summary.pdf

4. De Vita, G. (2002). Cultural equivalence in the assessment of home and international business management students: a UK exploratory study, Studies in Higher Education, 27, 221-231.

5. Dobson, I.R., Sharma, R., \& Calderon, A.J. (1998). The comparative performance of overseas and Australian undergraduates, in: D. Davis \& A. Olsen (Eds) Outcomes of international education: research findings, a set of commissioned research papers presented at the 12th Australian International Education Conference, Canberra 1998 (Canberra, IDP Education Australia).

6. Jochems, W., Snippe, J., Smid, H.J., \& Verweij, A. (1996) The academic progress of foreign students: study achievement and study behaviour, Higher Education, 31, 325-340.

7. Hulick, C., \& Higginson, B. (1989). The use of learning and study strategies by college freshmen, paper presented at the Annual Meeting of the Mid-South Educational Research Association, Little Rock, Arkansas.

8. Kamariah Abu Bakar, Rohani Ahmad Tarmizi, Rahil Mahyuddin, Habibah Elias, Wong, S.L., \& Ahmad Fauzi Mohd Ayub. (2010). Relationships between university students' achievement motivation, attitude and academic performance in Malaysia. Procedia Social and Behavioral Sciences 2, 4906-4910.

9. MacNamara, D., \& Penner, K. (2005). First-year math students: using study skills and motivation to predict academic success (Kwantlen University College). Retrieved 2 November, 2010 from http://www.mykwantlenpolytechnicuniversity.com/_shared/assets/Math_Retention_Study2878.pdf

10. Makepeace, E., \& Baxter, A. (1990). Overseas students and examination failure: a national study, Journal of International Education, 1(1), 36-48.

11. Ministry of Higher Education (2008). Perangkaan pengajian tinggi Malaysia, 2008 [Statistics of higher education of Malaysia, 2008]. Retrieved 19 September, 2011 from http://www.mohe.gov.my/web_statistik/Buku_Perangkaan_2008.pdf

12. Ministry of Higher Education (2009). Perangkaan pengajian tinggi Malaysia, 2009 [Statistics of higher education of Malaysia, 2009]. Retrieved 19 September, 2011 from http://www.mohe.gov.my/web_statistik/satistik_2009.htm

13. Ministry of Higher Education (2010). Perangkaan pengajian tinggi Malaysia, 2010 [Statistics of higher education of Malaysia, 2010]. Retrieved 19 September, 2011 from http://www.mohe.gov.my/web_statistik/perangkaan_2010.pdf

14. Morrison, J., Merrick, B., Higgs, S., \& Le Métaisa, J. (2005). Researching the performance of international students in the UK, Studies in Higher Education, 30(3), 327-337.

15. Morshidi Sirat. (2008). The impact of September 11 on international student flow into Malaysia: lessons learned. International Journal of Asia-Pacific Studies, 4(1), 79-95.

16. National Higher Education Research Institute (2009). Kajian pelajar antarabangsa di Malaysia: Laporan akhir. [Survey of international students in Malaysia: Final report]. Retrieved 12 October, 2011 from http://jpt.mohe.gov.my/PENYELIDIK/penyelidikan\%20IPPTN/Laporan\%20akhir\%20KajPeljAntrbgsa_T NR ipptnformat.pdf

17. Nist, S.L., Mealey, D.L., Simpson, M. L., \& Kroc, R. (1990). Measuring the affective cognitive growth of regularly admitted and developmental studies students using the learning and study strategies inventory. Reading Research and Instruction, 30, 44-49.

18. Olaussen, B.S., \& Braten, I. (1999). Students' use of strategies for self-regulated learning: cross-cultural perspectives. Scandinavian Journal of Educational Research, 43(4), 409-432.

19. Pauley, G.F. (1988). Overseas-fee-paying students at Curtin University of Technology: a report on their progress after one year (Perth, Curtin University of Technology). 
20. Pillay, H., Purdie, N., \& Boulton-Lewis, G. (2000). Investigating cross-cultural variation in conceptions of learning and the use of self-regulated strategies. Education Journal, 28(1), 65-84.

21. Purdie, N., Hattie, J., \& Douglas, G. (1996). Student conceptions of learning and their use of self-regulated learning strategies: a cross-cultural comparison. Journal of Educational Psychology, 88(1), 87-100.

22. Reaser, A., Prevatt, F., Petscher, Y., \& Proctor, B. (2007). The learning and study strategies of college students with ADHD. Psychology in the Schools, 44(6), 627-638.

23. Rohaizat Baharun, Zubaidah Awang, \& Siti Falinda Padlee. (2011). International students choice criteria for selection of higher learning in Malaysian private universities. African Journal of Business Management, 5(12), 4704-4714.

24. Rohana Jani, Yong Zulina Zubairi, Huam, H.T., \& Abdul Hafaz Ngah. (2010). International students’ views of Malaysian higher education, paper presented at Internationalisation and Marketing of Higher Education Malaysia Seminar, Putrajaya, Malaysia. Retrieved 10 October, 2011 from http://www.iranscap.com/wp-content/uploads/2011/08/International-Students-Views-of-Malaysian-HigherEducation-1.pdf

25. Schunk, D.H., \& Zimmerman, B.J. (2008). Motivation and self-regulated learning: theory, research and applications. New York: LEA.

26. Smith, Y.M., \& Eccles, T. (1993). An investigation into the learning experience of overseas students: a pilot study (School of Surveying Occasional Paper no. 3). (London, Kingston University).

27. Stoynoff, S. (1996). Self-regulated learning strategies of international students: a study of high- and lowachievers. College Student Journal, 30(3), 329-336.

28. Stoynoff, S. (1997). Factor associated with international students' academic performance. Journal of Instructional Psychology, 24(1), 56-68.

29. Turingam, L.P., \& Yang, Yong-Chil. (2009). A cross-cultural comparison of self-regulated learning skills between Korean and Filipino college students. Asian Social Science, 5(12), 3-10.

30. Wadsworth, L.M., Husman, J., Duggan, M.A., \& Pennington, M.N. (2007). Online mathematics achievement: effects of learning strategies and self-efficacy. Journal of Developmental Education, 30(3), 614.

31. Weinstein, C.E., Palmer, D.R., \& Shulte, A.C. (2002). Learning and Study Strategies Inventory (LASSI), second edition. $\mathrm{H} \& \mathrm{H}$ Publishing Inc.

32. Williams, Sir B. (Ed.) (1989). Overseas students in Australia: policy and practice (Canberra, International Development Program of Australian Universities and Colleges).

33. Yip, M.C.W., \& Chung, O.L.L. (2005). Relationship of study strategies and academic performance in different learning phases of higher education in Hong Kong. Educational Research and Evaluation, 11(1), 61-70. 